\title{
「女性医師が働きやすい病院」チェックリストの開発
}

\author{
堀江 早喜 $* 1$, 竹内 真純 $* 1$, 山岡 和枝 $*^{2}$, 野原 理子 $*^{3}$, \\ 蓮沼 直子 $*^{4}$, 冲永 寛子 $*^{1}$, 野村 恭子 $* 1,2,5$ \\ *1 帝京大学女性医師・研究者支援センター \\ $*^{2}$ 帝京大学大学院公衆衛生学研究科 \\ $*^{3}$ 東京女子医科大学医学部医学科衛生学公衆衛生学教室 \\ $*^{4}$ 秋田大学医学部総合地域医療推進学講座 \\ $*^{5}$ 帝京大学医学部衛生学公衆衛生学講座
}

\section{Checklist Development for Women-Doctor-Friendly Working Conditions in a Hospital Setting}

\author{
Saki HORIE*1, Masumi TAKEUCHI*1, Kazue YAMAOKA*2, Michiko NOHARA*3, \\ Naoko HASUNUMA*4, Hiroko OKINAGA*1 and Kyoko NOMURA*1,2,5 \\ ${ }^{* 1}$ Teikyo University, Support Center for Women Physicians and Researchers \\ *2Teikyo University, Graduate School of Public Health \\ *3epartment of Hygiene and Public Health 1, Tokyo Women's Medical University \\ *4Department of Community Medicine and Primary Care Development, Akita University School of Medicine \\ ${ }^{*}$ Department of Hygiene and Public Health, Teikyo University School of Medicine
}

\begin{abstract}
Objectives: This study aims to develop a scale of "women-doctor-friendly working conditions in a hospital setting".

Methods: A task team consisting of relevant people including a medical doctor and a hospital personnel identified 36 items related to women-doctor-friendly working conditions. From December in 2012 to January in 2013, we sent a self-administered questionnaire to 807 full-time employees including faculty members and medical doctors who worked for a university-affiliated hospital. We asked them to score the extent to which they think it is necessary for women doctors to balance between work and gender role responsibilities on the basis of the Likert scale. We carried out a factor analysis and computed Cronbach's alpha to develop a scale and investigated its construct validity and reliability.

Results: Of the 807 employees, 291 returned the questionnaires (response rate, $36.1 \%$ ). The item-total correlation (between an individual item score and the total score) coefficient was in the range from 0.44 to 0.68. In factor analysis, we deleted six items, and five factors were extracted on the basis of the least likelihood method with the oblique Promax rotation. The factors were termed "gender equality action in an organization", "the compliance of care leave in both sexes and parental leave in men", "balance between life events and work", "childcare support at the workplace", and "flexible employment status". The Cronbach's alpha values of all the factors and the total items were $0.82-0.89$ and 0.93 , respectively, suggesting that the scale we developed has high reliability.

Conclusions: The result indicated that the scale of women-doctor-friendly working conditions consisting of five factors with 30 items is highly validated and reliable.
\end{abstract}

Key words: woman doctor（女性医師）, scale development（尺度開発）, working condition（就労状況）, hospital workplace（病院の職場）, life event（ライフイベント）

受付 2014 年 11 月 27 日, 受理 2015 年 1 月 13 日

Reprint requests to: Saki HORIE

Teikyo University, Support Center for Women Physicians and Researchers, 2-11-1 Kaga, Itabashi-ku, Tokyo 173-8605, Japan TEL: +81(3)3964-8456, FAX: +81(3)3964-8457

E-mail: saki-h@med.teikyo-u.ac.jp
はじめに

2012 年の医師・歯科医師・薬剂師調査（1）によれば, 我が国の医師数は人口 1,000 人当たり 2.4 人であり, OECD (Organisation for Economic Cooperation and Devel- 
opment）諸国に打ける平均医師数の 3.2 人（2011 年）よ り低い(2)。このように我が国は深刻な医師不足に直面 して打り, 日本政府は2010年より全国医学部の定員数 を増員させ医師数を増加させる政策をとっている。しか し, 一人前の医師になるまでに医学部 6 年, 研修医 2 年, さらに診療科にもよるが専門医まで 3 年とすると, 少な くとも 11 年と時間がかかる。よって, 現在有資格者で ある女性医師の社会活用は費用対効果からみても優先的 に取り組むべき事項と考えられよう。ところが泉らによ れば，医学部卒業後 10 年以内に離職を経験している女 性は $85 \%$ であり, 一度常勤を退くと常勤に復職する割 合は 3 割程度であることが報告されている（3）。また同 報告によれば，常勤を辞めた理由の第一位は「子どもの 出産」, 第二位に「子育て」とあり女性医師は出産・子 育てのライフイベントに遭遇した際に仕事との両立が困 難であることが主な原因であることされている。さらに, 安川らによれば, 週当たりの家事労働時間は, 子どもの いない女性医師は 15 時間, 子ぞものいる女性医師は 36 時間に比べ，子どものいない男性医師はわずか 2 時間で あり，子どもがいる男性医師でも 3 時間であった。この ことから女性医師は男性医師に比べはるかに家事労働時 間は長く, 有資格者とはいえ男女の性別役割分業が根付 よく浸透していることが明らかとなった（4）。我が国の 年代別就業率 (5) の特徴は, 子どもを産久育てる 20 代 後半から 40 代前半に就労率が下がることで形成される $\lceil\mathrm{M}$ 字カーブ」が知られている。この $\mathrm{M}$ 字カーブは日本 と韓国のみ見られ, 両国に抢ける女性医師の全医師数に 占める割合は OECD 諸国の中で最低となっている (2)。

そこで本研究の目的は，医師不足対策の一環として， 女性医師が離職せずキャリアを構築し両立させながら就 労するために必要な職場環境尺度を開発することであ る。本研究の結果より, 女性医師を雇用する医療機関に 対し, 必要な職場環境の具体的なチェックリストを提示 することが可能となる。

\section{対象と方法}

\section{1. 研究チームによる尺度原案の作成}

先行研究の既存文献 $(3,4,6)$ 拈よび労働基準法 (7), 育児・介護休業法 (8), 短時間正社員制度 (9)をもとに 尺度項目を抽出し，医師，看護師，薬剤師，病院総務課， 人事課などの女性医師の就労に関し，経験と知識のある 研究チームにて尺度項目を精選した。精選した尺度項目 のスキームとして，その意味内容ょり「保育支援」，「労 働基準法に遵守した働き方」,「組織のリーダーシップ」, 「柔軟性のある働き方」,「男性医師・組織の意識改革」,「相 談空口」，「男女共同参画の教育体制」と設定した。その 後, 尺度原案の作成に向けて研究チームにおいて協議し, 設問, 注釈の必要性，選択肢について検討した。尺度原 案作成の際, 設問は年齢, 所属, 婚姻状況, 子ぞもの有 無などに関わらず回答できるように配慮し, 経験年数や
婚姻状況にばらつきのある男女の医師 10 人を対象に pretest を行い，尺度項目の表現を修正した。

\section{2. 尺度開発}

\section{(1) 調査対象}

調査対象は，某大学医療系キャンパスの常勤職員と附 属病院の研修医，大学院生の 809 名を対象とした。内訳 は，医学部所属の女性 56 名と男性 357 名の 413 名（基 礎 71 名, 臨床 342 名), 薬学部所属の女性 25 名之男性 79 名の 104 名, 医療技術学部所属の女性 36 名と男性 25 名の 94 名, 研修医 93 名（初期：女性 13 名と男性 40 名 の 53 名, 後期: 女性 14 名と男性 26 名の 40 名), 大学 院生である女性 32 名と男性 73 名の 105 名である。倫理 上の配慮として, 帝京大学医学部倫理委員会の承認を得 た（帝倫 $12-71$ 号 平成 24 年 9 月 1 日）。

\section{（2）調査方法と項目}

2012 年 12 月～ 2013 年 1 月に無記名自記式の質問紙 調査を行った。調査項目は，36 項目の環境尺度と基礎 属性，婚姻状況，子ぞもの有無，保育室利用の希望扣よ び介護の状況を含めた。環境尺度については，各項目に ついて「女性医師が働きやすい職場つくりに際し，どの くらい必要でしょらか」と尋ねた。選択肢は「絶対必要 である」から「まったく必要ない」の 5 段階による Likert scale とした。

本研究は某大学の男女共同参画活動の一環として行 い，対象者に調査票とともに調査協力依頼書，同意書を 郵送した。回収率を上げるために, 学内リマインダーメー ルを配信した。調査参加者は同意書に同意の上，同意書 とは別に用意した返信用封筒にて研究者宛に返送するよ ら依頼した。

\section{（3）分析方法}

分析方法は, 弁別力のある項目の決定を行らため, 各 項目得点と総項目の合計との相関係数である項目一全体 相関（Item-Total 相関係数：以下， I-T 相関係数）を算出 した。項目一全体相関は有意差のない項目は削除すると されている $(10)$ 。その後, 構成概念妥当性の検討のため, 重久付けのない最小二乗法扎よびプロマックス回転によ る因子分析を行った。各因子の構成項目から求めた得点 （尺度）の内的一貫性信頼性についてクロンバック $\alpha$ 係 数を算出した。性別, 婚姻状況, 子どもの有無, 職位に よる比較を行らため Student の $\mathrm{t}$ 検定を行った。有意水 準は 0.05 とした。分析には統計パッケージ SAS (version 9.3）を用いた。

\section{結果}

調査票の回収数は291 (36.0\%), 性別は女性 107 名, 男性 178 名であった。対象者の基本属性を表 1 に示す。 年齢の平均值，標準偏差は，女性 $42.2 \pm 11.4$ 歳，男性 $46.4 \pm 10.1$ 歳であった。教員の有無については教授・准 教授・講師・助教からなる教員の男女構成は，女性 58 
表 1 対象者の属性（N=291）

\begin{tabular}{|c|c|c|c|c|}
\hline 項目 & \multicolumn{2}{|c|}{ 内訳 } & 人数 & $\%$ \\
\hline \multirow[t]{5}{*}{ 年齢 } & \multicolumn{2}{|c|}{$23 \sim 29$ 歳 } & 18 & 6.2 \\
\hline & \multicolumn{2}{|c|}{$30 \sim 39$ 歳 } & 85 & 29.2 \\
\hline & \multicolumn{2}{|c|}{$40 \sim 49$ 歳 } & 73 & 25.1 \\
\hline & \multicolumn{2}{|c|}{$50 \sim 59$ 歳 } & 73 & 25.1 \\
\hline & \multicolumn{2}{|c|}{$60 \sim 69$ 歳 } & 30 & 10.3 \\
\hline \multirow[t]{2}{*}{ 性別 } & \multirow{2}{*}{\multicolumn{2}{|c|}{$\begin{array}{l}\text { 女性 } \\
\text { 男性 }\end{array}$}} & 107 & 36.8 \\
\hline & & & 178 & 61.2 \\
\hline \multirow[t]{12}{*}{ 職位＊ } & \multirow[t]{5}{*}{ 教員 } & 教授 & 68 & 23.4 \\
\hline & & 准教授 & 34 & 11.7 \\
\hline & & 講師 & 44 & 15.1 \\
\hline & & 助教 & 61 & 21.0 \\
\hline & & 計 & 207 & 71.2 \\
\hline & \multirow[t]{7}{*}{ 教員以外 } & 研修医 & 5 & 1.7 \\
\hline & & 研修生 & 4 & 1.4 \\
\hline & & 医員 & 3 & 1.0 \\
\hline & & 研究助手 & 5 & 1.7 \\
\hline & & 臨床助手 & 23 & 7.9 \\
\hline & & その他 & 39 & 13.4 \\
\hline & & 計 & 79 & 27.1 \\
\hline \multirow[t]{2}{*}{ 婚姻状況 } & \multicolumn{2}{|l|}{ 独身 $* *$} & 88 & 30.2 \\
\hline & \multicolumn{2}{|l|}{ 既婚 } & 201 & 69.1 \\
\hline \multirow[t]{2}{*}{ 子ども } & \multirow{2}{*}{\multicolumn{2}{|c|}{$\begin{array}{l}\text { なし } \\
\text { あり }\end{array}$}} & 113 & 38.8 \\
\hline & & & 164 & 56.4 \\
\hline
\end{tabular}

$\mathrm{N}$ に満たさない項目は欠損値あり

* 職位は教員 (教授・准教授・講師・助教), 教員以外 (研修医・ 研修生・医員・研究助手・臨床助手・その他）

***独身は死別・離婚含む

名 $(54.7 \%)$, 男性 147 名 $(84.0 \%)$ であり, 教員以外は 女性 48 名 (45.3\%), 男性 28 名 (16.0\%) であった。婚 姻状況は, 独身（離婚・死別を含む）が女性 52 名 (49.1\%), 男性 33 名 (18.5\%), 子どものいる者は女性 38 名 (35.5\%), 男性 123 名 (69.1\%) であった。

尺度原案の各項目に関寸る度数分布, 平均值, 標準偏 差を表 2 に示す。各項目の平均値は最小 $3.4 \sim$ 最大 4.6 （5 点満点）であった。 I-T 相関係数は， $0.46 〜 0.70$ の範 囲であった。本研究に打いては削除の対象となりらる項 目はなかった。構成概念妥当性を検証するため, 36 項 目について因子分析（最小二乗法，プロマックス回転） を行った。固有值 1 以上では，スクリープロット抏よび 解釈可能性から因子数を 5 と判断し，30 項目とした。 これらの 30 項目を再度行った因子分析結果を表 3 に示 す。すべての項目の因子負荷量は 0.35 以上となり各因 子に含まれる項目の意味内容に矛盾のない最適解を得 た。因子間相関は， $0.37 〜 0.52$ の範囲であった。

第 1 因子は〈就労・キャリアなどの相談空口〉, 〈管理 職に女性の登用〉などからなる 10 項目から構成された。 この因子は，男性が大半を占める「医師」の職場環境対 策としての重要な取り組みと解釈し『男女共同参画への 組織的な取り組み』と命名した。第 2 因子は〈産前・産
後休㗇〉,〈労働基準法の遵守〉などからなる 9 項目から 構成され，『ライフイベントと仕事の両立』と命名した。 第 3 因子は〈職場保育所〉,〈保育支援体制〉などからな る 5 項目から構成され，『保育体制の整備』と命名した。 第 4 因子は〈男性の育児・介護休暇取得〉, 〈女性の介護 休暇取得〉からなる 3 項目から構成された。この因子は, 現時点で取得できていない法的休暇環境であることを鑑 久，『介護休㗇・男性の育児休暇』と命名した。第 5 因 子は 3 項目から構成され,『柔軟な勤務形態』と命名した。

また，信頼性の検討のためクロンバック $\alpha$ 係数を算出 したところ，いずれの因子打よび全体においても 0.80 以上であり (表 3)，内部一貫性が見られた。表 4 に $\mathrm{t}$ 検 定による性別や婚姻状況，子ぞもの有無，職位による各 因子の平均点の比較を示す。性別については, 『男女共 同参画への組織的な取り組久』, 『保育体制の整備』、『 護休㗇・男性の育児休㗇』, 『柔軟な勤務形態』の 4 因子 については，女性が男性よりも平均值が有意に高かった （p 值 $<0.05 ） 。 一$ 方，婚姻状況ならびに子どもの有無， 職位に打いては，2 群で差は認められなかった。

\section{考察}

本研究の目的は,「女性医師が働きやすい病院」の構 成概念を明らかにすることである。女性医師の就労に関 し専門知識のある研究チームにより, 選定した 36 項目 を用い因子分析を行った。因子分析では，5因子 30 項 目から成る尺度が得られ，各因子名は『男女共同参画へ の組織的な取り組み』,『ライフイベントと仕事の両立』, 『保育体制の整備』，『介護休㗇・男性の育児休暇』『柔軟 な勤務形態』と命名した。

本研究の対象者は一私立医科大学・附属病院の教員と その他の臨床医, 研究員などの職員である。サンプルサ イズがやや少なく, 単一の大学病院であることから結果 の一般化には限界がある。さらに, 本研究の対象集団の 特性を見ると，ライフイベントに遭遇している該当者が 少なかったこと，独身者が少なかったことよりニーズの あるものの回答数が少なく，この点については結果を慎 重に考慮する必要がある。現実的に職場でも家庭でも保 育支援が得られていない当事者に沶いては，忙しくて調 査に参加する余裕がないことは当たり前かもしれない。

しかしながら，この尺度が女性医師の就労環境整備を 目的に作成された趣旨を考慮すると，将来的にこの尺度 を用いる対象者は病院医療機関の事業主拈よび管理職が 想定される。この点に打いて本研究の対象集団は 7 割が 管理職の立場にある教員であり，用いた回答者データは 想定する概念的母集団と近似していた。さらに確認のた め，職位の違い，婚姻状況ならびに子ぞもの有無におい て，第 1 因子から第 5 因子の平均值に違いがあるか検討 したが，有意差は認められず様々なライフステージに拉 いて適応可能な尺度であると思われる。

本研究により女性医師が働きやすい病院のチェックリ 


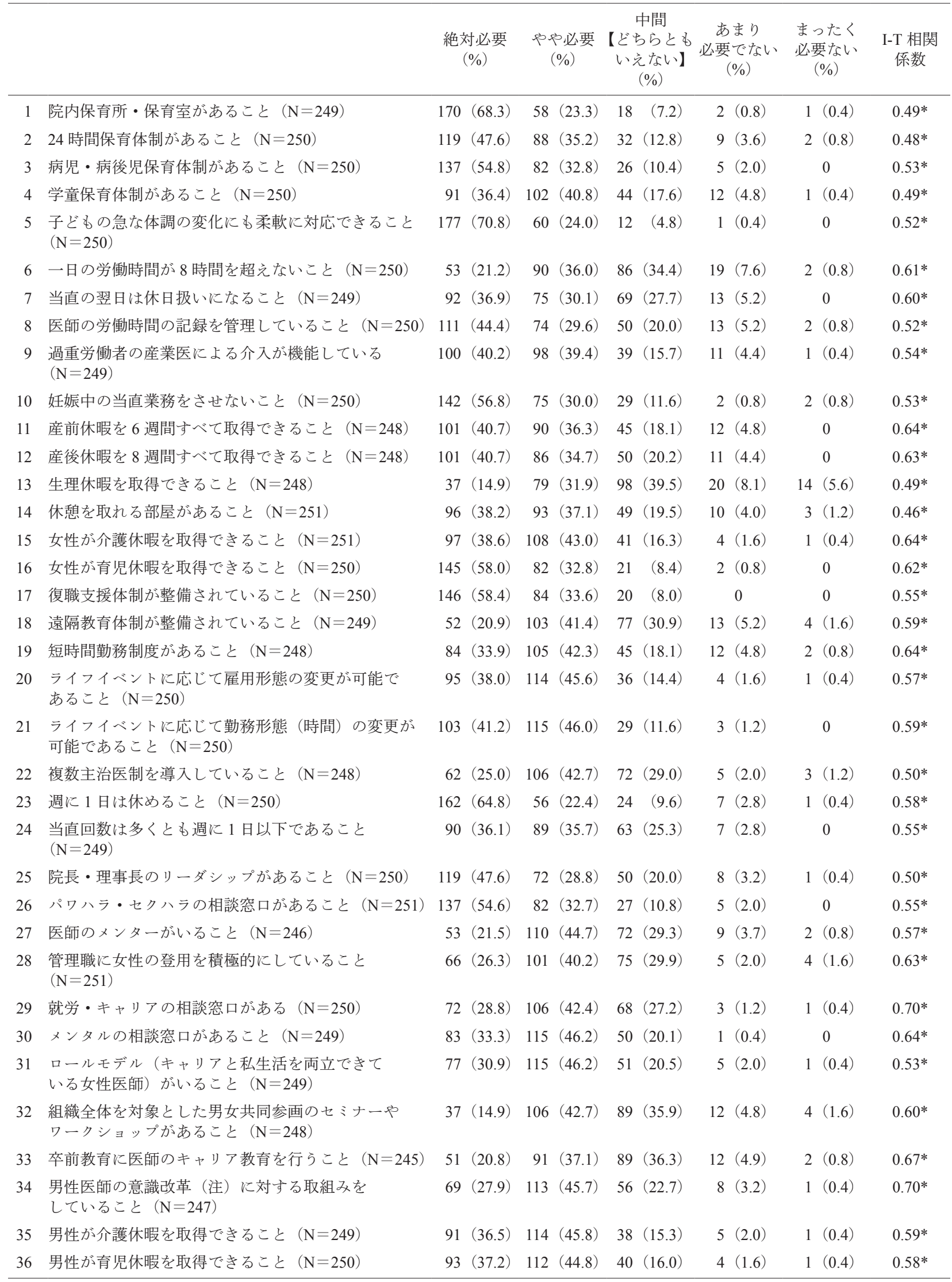

（注）女性には社会的な女性としての役割分担（妻・母・娘として）があり，この性別役割分担の見直しが重要といわ机ています。 $* \mathrm{p}<0.001$ 


\begin{tabular}{|c|c|c|c|c|c|}
\hline 項目 & 第 1 因子 & 第 2 因子 & 第 3 因子 & 第 4 因子 & 第 5 因子 \\
\hline \multicolumn{6}{|l|}{ 第 1 因子 10 項目「男女共同参画への組織的な取組」 $\alpha=0.89$} \\
\hline 医師のメンターがいること & 0.69 & -0.02 & 0.00 & 0.01 & -0.02 \\
\hline パワハラ・セクハラの相談空口があること & 0.68 & 0.10 & -0.08 & -0.11 & 0.02 \\
\hline 就労・キャリアの相談空口がある & 0.68 & 0.10 & -0.07 & 0.11 & 0.05 \\
\hline 管理職に女性の登用を積極的にしていること & 0.64 & -0.10 & 0.02 & 0.21 & 0.01 \\
\hline メンタルの相談空ロがあること & 0.61 & 0.13 & -0.05 & 0.13 & -0.03 \\
\hline 院長・理事長のリーダシップがあること & 0.60 & 0.02 & 0.06 & -0.15 & 0.04 \\
\hline 組織全体を対象とした男女共同参画のセミナーやワークショップがあること & 0.55 & -0.03 & 0.14 & 0.15 & -0.07 \\
\hline ロールモデル（キャリアと私生活を両立できている女性医師）がいること & 0.53 & -0.09 & -0.04 & 0.10 & 0.17 \\
\hline 卒前教育に医師のキャリア教育を行らこと & 0.47 & 0.10 & 0.10 & 0.28 & -0.10 \\
\hline 男性医師の意識改革に対する取組みをしていること & 0.42 & -0.03 & 0.14 & 0.28 & 0.14 \\
\hline \multicolumn{6}{|l|}{ 第 2 因子 9 項目「ライフイベントと仕事の両立 $」 \alpha=0.84$} \\
\hline 産後休暇を 8 週間すべて取得できること & -0.13 & 0.70 & 0.00 & 0.30 & -0.02 \\
\hline 産前休暇を 6 週間すべて取得できること & -0.11 & 0.66 & -0.02 & 0.33 & 0.00 \\
\hline 妊娠中の当直業務をさせないこと & -0.04 & 0.62 & 0.01 & 0.12 & -0.04 \\
\hline 一日の労働時間が 8 時間を超えないこと & 0.12 & 0.59 & 0.04 & -0.17 & 0.16 \\
\hline 当直の翌日は休日扱いになること & 0.10 & 0.58 & 0.01 & -0.04 & 0.08 \\
\hline 過重労働者の産業医による介入が機能している & 0.44 & 0.48 & -0.03 & -0.20 & -0.11 \\
\hline 医師の労働時間の記録を管理していること & 0.34 & 0.47 & -0.01 & -0.23 & 0.00 \\
\hline 生理休暇を取得できること & 0.14 & 0.37 & 0.01 & 0.06 & -0.01 \\
\hline 女性が育児休艰を取得できること & -0.01 & 0.35 & 0.12 & 0.31 & 0.08 \\
\hline \multicolumn{6}{|l|}{ 第 3 因子 5 項目「保育体制の整備」 $\alpha=0.83$} \\
\hline 病児・病後児保育体制があること & 0.00 & -0.01 & 0.86 & -0.13 & 0.07 \\
\hline 24 時間保育体制があること & -0.03 & -0.08 & 0.80 & 0.11 & -0.07 \\
\hline 学童保育体制があること & 0.02 & 0.04 & 0.72 & -0.01 & -0.08 \\
\hline 院内保育所・保育室があること & 0.01 & 0.04 & 0.62 & -0.05 & 0.07 \\
\hline 子供の急な体調の変化にも柔軟に対応できること & -0.01 & 0.11 & 0.46 & 0.05 & 0.13 \\
\hline \multicolumn{6}{|l|}{ 第 4 因子 3 項目「介護休暇・男性の育児休暇」 $\alpha=0.82$} \\
\hline 男性が育児休服を取得できること & 0.02 & 0.02 & -0.05 & 0.87 & 0.02 \\
\hline 男性が介護休暇を取得できること & 0.07 & -0.02 & -0.05 & 0.84 & 0.04 \\
\hline 女性が介護休叞を取得できること & 0.12 & 0.26 & 0.16 & 0.37 & -0.05 \\
\hline \multicolumn{6}{|l|}{ 第 5 因子 3 項目「柔軟な勤務形態」 $\alpha=0.87$} \\
\hline ライフイベントに応じて雇用形態の変更が可能であること & 0.00 & 0.00 & -0.06 & 0.00 & 0.95 \\
\hline ライフイベントに応じて勤務形態（時間）の変更が可能であること & -0.03 & 0.03 & 0.05 & 0.02 & 0.86 \\
\hline 短時間勤務制度があること & 0.11 & 0.03 & 0.11 & 0.08 & 0.61 \\
\hline \multicolumn{6}{|l|}{ 因子間相関 } \\
\hline 第 1 因子 & 1.00 & & & & \\
\hline 第 2 因子 & 0.52 & 1.00 & & & \\
\hline 第 3 因子 & 0.38 & 0.40 & 1.00 & & \\
\hline 第 4 因子 & 0.40 & 0.39 & 0.43 & 1.00 & \\
\hline 第 5 因子 & 0.42 & 0.40 & 0.43 & 0.37 & 1.00 \\
\hline
\end{tabular}

ストは，5因子で構成される 30 項目となった。尺度原 案に打ける 36 項目のらち, 6 項目は因子分析の過程に おいて除外した。これらの除外項目は，「休憩を取れる 部屋があること」，「復職支援体制が整備されているこ と」，「遠隔教育体制が整備されていること」，「複数主治 医制を導入していること」,「週に 1 日は休めること」,「当 直回数は多くとも週に 1 日以下であること」であった。 除外した 6 項目については, 「複数主治医制を導入して
いること」は，がん患者などの診療に扣いて主治医が変 わることは好ましい状況とはいいがたい。「週に 1 日は 休めること」, 「当直回数は多くとも週に 1 日以下である こと」については, 各診療科のマンパワーに依存する項 目である。「休馝を取れる部屋があること」については, 医療法（11）に基づく設置基準より患者の占有スペース が優先される現状がある。「復職支援体制が整備されて いること」と「遠隔教育体制が整備されていること」に 
表 4 性別・婚姻状況 -子どもの有無・職位による各因子の平均点の比較 *

\begin{tabular}{|c|c|c|c|c|c|c|c|c|c|c|c|c|}
\hline & \multicolumn{3}{|c|}{ 性別 } & \multicolumn{3}{|c|}{ 婚姻状況 } & \multicolumn{3}{|c|}{ 子ども } & \multicolumn{3}{|c|}{ 職位 *** } \\
\hline & $\begin{array}{c}\text { 女 } \\
(\mathrm{N}=107)\end{array}$ & $\begin{array}{c}\text { 男 } \\
(\mathrm{N}=178)\end{array}$ & $\mathrm{p}$ 值 & $\begin{array}{l}\text { 独身 ** } \\
(\mathrm{N}=88)\end{array}$ & $\begin{array}{c}\text { 既婚 } \\
(\mathrm{N}=201)\end{array}$ & $\mathrm{p}$ 值 & $\begin{array}{c}\text { 有 } \\
(\mathrm{N}=164)\end{array}$ & $\begin{array}{c}\text { 無 } \\
(\mathrm{N}=113)\end{array}$ & $\mathrm{p}$ 值 & $\begin{array}{c}\text { 教員 } \\
(\mathrm{N}=207)\end{array}$ & $\begin{array}{l}\text { その他 } \\
(\mathrm{N}=79)\end{array}$ & $\mathrm{p}$ 值 \\
\hline $\begin{array}{l}\text { 男女共同参画への } \\
\text { 組織的な取組 }\end{array}$ & 41.0 & 39.0 & 0.02 & 40.5 & 39.3 & 0.15 & 40.0 & 39.3 & 0.38 & 39.9 & 39.3 & 0.45 \\
\hline $\begin{array}{l}\text { ライフイベントと } \\
\text { 仕事の両立 }\end{array}$ & 37.2 & 36.0 & 0.11 & 36.3 & 36.5 & 0.86 & 36.5 & 36.3 & 0.76 & 36.7 & 35.8 & 0.26 \\
\hline 保育体制の整備 & 22.7 & 21.7 & 0.01 & 21.8 & 22.1 & 0.46 & 22.2 & 21.9 & 0.41 & 22.0 & 21.9 & 0.73 \\
\hline $\begin{array}{l}\text { 介護休㗇・男性の } \\
\text { 育児休㗇 }\end{array}$ & 13.1 & 12.2 & 0.001 & 12.6 & 12.5 & 0.69 & 12.6 & 12.4 & 0.63 & 12.5 & 12.5 & 0.97 \\
\hline 柔軟な勤務形態 & 13.2 & 12.1 & $<.001$ & 12.8 & 12.4 & 0.12 & 12.4 & 12.7 & 0.24 & 12.3 & 12.8 & 0.10 \\
\hline
\end{tabular}

* Student の t 検定による

***独身は死別・離婚含む

***職位は教員 (教授・准教授・講師・助教)，その他（研修医・研修生・修練生・医員・教務職員・研究助手・臨床助手・病院教授・ 病院准教授・その他)

ついては，同じくマンパワーの問題や IT 環境整備の拡 充に向けた費用の問題など医療機関個別の状況がある。 しかし，これら 6 項目は半数以上が必要であると回答し ていたことや女性医師の就労環境整備上重要ではある が，類似の項目が少なかったため共通因子が得られな かったと考える。

尺度の理論的整合性について既存文献との比較から以 下に考察する。第 1 因子は相談空口や女性の登用, 組織 改革より構成された『男女共同参画への組織的な取り組 み』は, 医療機関における女性医師の職場環境を改善さ せるために最も重要である（12）。我々が行った 13 医科 大学を対象に行った先行研究では, 性別のために有給ポ ス卜獲得・昇進人事・終身雇用の機会を得られなかった 割合は女性で $21 \%$ ，男性で $3 \%$ であった $(\mathrm{p}<0.0001) 。$ こうした就労機会の性別格差は男女の就労パターンに大 きく影響を与え, 男女の就労格差を強く認知している者 は認知してない者に比べ，パートタイムワーカーになり やすいことが明らかとなっている(13)。別の先行研究 では，女性は男性に比べ自己評価が厳しく，たとえ同等 に仕事のパフォーマンスができていても自信が低くなる 傾向が知られている（14）。こうした自信の低さや男女 就労格差の認知は, 医師の労働特性が肉体的な労働であ り女性にとってはハンディであることが影響していると 報告されている (15)。よって, 相談空口設置や女性の 登用によるロールモデルの存在, 組織の意識改革, 卒前 教育介入など男女共同参画の特徵が表れていると考えら れる。第 2 因子の『ライフイベントと仕事の両立』につ いては，日本医師会の調査（6）より「産前・産後休暇を 取得しなかった割合」は $20 \%$ であることがわかった。 産前・産後休㗇を取得するという労働基準法を遵守でき ない活どの劣悪な医師の就労状沉が蔓延して扔り，早急 な労働環境の改善が必要である。労働政策研究・研修機 構調査（16）によれば，勤務医の $40 \%$ が週 60 時間以上 の過重労働が明らかとなっている。さらに, 日本医療労 働組合連合会の調査 (17) に括いて, 約 9 割は交代制勤
務がなく，宿直翌日の勤務体制は，「通常通り勤務する」 が約 $80 \%$ を占める。こうした過重労働が曼延している 状況に颃いては，子ぞもを持つ，あるいは性別役割分業 を周囲から期待される女性医師が仕事と両立することは 難しい。第 3 因子の『保育体制の整備』については，女 性医師が出産，子育てなどのライフイベントの遭遇時期 が丁度，認定専門医に必要な病院の修練の時期と重なる ため保育支援が重要な課題である。ただし病院保育所の 運営は常に赤字採算部門であり，公的補助金を受けてい ない病院に扎いては保育所を自前で設置するほどの余裕 はないであろら。その場合には, ベビーシッターやファ ミリーサポートの情報提供などソフト面の支援の充実を 代替項目として用いるなど応用があってもよいと思われ る。第 4 因子の『介護休暇・男性の育児休㗇』について, 労働政策研究・研修機構の調査研究 (18) によれば, 介 護休暇を「取得したい」とする正規雇用・主介護者は $45.9 \%$ であるにもかかわらず，年間の介護休暇日数は 5 日を超えていないとある。また，他の調査に拈いて子常 用労働者に占める介護休暇取得者の割合は $0.14 \%$ であ り（19），介護休暇は産休や育児休暇以上に取得率が低 い現状がある。男女問わず年老いた親の面倒などの休㗇 が取得できるよう，男性に打ける育児休暇とともに重要 な取り組み課題である。第 5 因子の『柔軟な勤務形態』 はライフイベントに対応できる勤務環境と育児・介護休 業法（8）にある短時間勤務制度が含まれている。これら の項目が独立した因子として抽出された背景には労務環 境面からみた管理体制が職場にあることが望まれている 状況がある。

本研究の限界については，検討した尺度には，保育体 制の整備が因子として抽出されている。日本医師会総合 政策研究所の「院内保育所を含屯医師就労支援に関する 調査（2008 年）」（20）によれば，保育所の運営費は一施 設当たり年間 1,200 万円の赤字採算と公表されて扣り, この尺度を病床数の少ない一般病院に強いるのは到底で きない。しかし，医師不足の背景の中で卒後間もない若 
手の女性医師が修練を受ける場として大学病院や研修指 定病院などの大きな病床数持つ病院に扎いては, 女性医 師がライフイベントに遭遇しても離職しないで働き続け られるために保育体制の整備は必要であると考光る。 よって，そのような病院に执いては本研究で検討した尺 度を活用できるものと期待する。

本研究で抽出された 5 因子『男女共同参画への組織的 な取り組み』,『ライフイベントと仕事の両立』, 『保育体 制の整備』, 『介護休暇・男性の育児休暇』、『柔軟な勤務 形態』は, いずれもその名称から一般女性労働者にも共 通して応用できる環境整備項目である。しかし, 対象者 を変えれば, その職種や職場に応じた必要と思われる取 り組み項目が抽出されるわけで, 本研究も修練と子ぞも を産及育てる時期が重なることが問題となっている女性 医師を対象に分析をした結果，5つの因子が抽出された と解釈している。特に，5因子中，『男女共同参画への 組織的な取り組み』,『ライフイベントと仕事の両立』, 『保 育体制の整備』の3つは女性医師には特別に必要な因子 であり，一方『介護休㗇・男性の育児休㗇』、『柔軟な勤 務形態』はより一般の女性労働者全体に適応できると思 われる。

今後, 基準関連妥当性の検討の際, 抽出された 5 因子 について女性医師の常勤数なぞをアウトカムに病院対象 の調査を行らことなど検討の余地がある。本研究では医 師不足時代に怙忷る女性医師の人的資源をさらに活性化 させるため, 環境整備を目的にチェックリストを作成し た。女性医師は卒後 10 年以内に半数以上が常勤を離職す ることが先行研究から明らかにされており, 医師として 修練の時期と女性として子ぞもを産又㕕卆時期が重なり 問題となっている。本研究の結果, 若い女性医師を持つ 病院に抢汀る就労環境整備が一層進むことを渴望する。

\section{謝辞}

多忙な中，調查にご協力くださいました教職員拉よび 研修医の皆様に深謝いたします。本研究は, 科研費基盤 C『女性医師の就労拡充に向けた労衝衛生評価之職場環 境整備尺度の開発（研究課題番号：25460814）』の一部 として行われた。

本研究において, 利益相反に相当する事項はない。

\section{文献}

（1）医師・歯科医師・薬剂師調查の概況. 厚生労働省, 2012.

(2) Organisation for Economic Co-operation and Development. An Analysis of the OECD Health Data: Paris, France: Organisation for Economic Co-operation and Development, 2013.

(3) Izumi M, Nomura K, Higaki Y, Akaishi Y, Seki M, Kobayashi S, Komoda T, Otaki J. Gender role stereotype and poor working condition pose obstacles for female doctors to stay in full-time employment: alumnae survey from two private medical schools in Japan. Tohoku J Exp Med 2013;229:233-237.

（4）安川康介, 野村恭子. 医師に打将る性別役割分担一診 療時間と家事労働時間の男女比較. 医学教育学雑誌 2012;43:315-319.

（５）総務省統計局. 労働力調査, 2014. http://www.e-stat.go.jp/ SG1/estat/List.do?lid=000001120261（2014.8.25）

（6）日本医師会男女共同参画委員会・日本医師会医師再就 職支援事業. 女性医師の勤務環境の状沉に関する調査 報告書. 平成21年. http://dl.med.or.jp/dl-med/teireikaiken/ 20090408_2.pdf (2014.8.25)

（7）労働基準法（第 32 条）。最終改正：平成二四年六月 二七日法律第四二号. http://law.e-gov.go.jp/htmldata/ S22/S22HO049.html (2014.8.25)

（8）育児休業, 介護休業等育児又は家族介護を行ら労働者 の福祉に関する法律 ; 平成 21 年 6 月改正. http://www. mhlw.go.jp/topics/2009/07/tp0701-1.html (2014.8.25)

（9）厚生労働省, 短時間正社員制度導入支援ナビ。稼働日; 平成 20 年 12 月 1 日. http://tanjikan.mhlw.go.jp/ (2014. 8.25 )

（10）徳永幹雄. 体育・スポーツの心理尺度. 東京 : 不昧堂 出版, 2004, 218-223.

（11）医療法（第 4 章，第 1 節）。最終改正：平成二六年六 月二七日法律第九一号

(12) Yasukawa K, Nomura K. The perception and experience of gender-based discrimination related to professional advancement among Japanese physicians. Tohoku J Exp Med 2014;232:35-42.

(13) Nomura K, Gohchi K. The impact of gender-based obstacle on working status among women physicians in Japan. Soc Sci Med 2012;75:1612-1616.

(14) Nomura K, Yano E, Fukui T. Gender differences in clinical confidence: a nationwide survey of resident physicians in Japan. Acad Med 2010;85:647-653. doi: 10.1097/ACM. 0b013e3181d2a796.

(15) Blanch DC, Hall JA, Roter DL, Frankel RM. Medical student gender and issues of confidence. Patient Educ Couns 2008;72:374-381. doi: 10.1016/j.pec.2008.05.021. Epub $2008 \mathrm{Jul} 24$.

（16）独立行政法人 労働政策研究 - 研修機構, 勤務医の就 労実態と意識に関する調査. 平成 24 年. http://www. jil.go.jp/press/documents/20120904.pdf (2014.8.25)

（17）日本医療労働組合連合会，勤務医実態調査. 2012. http://www.irouren.or.jp/old/jp/html/menu6/index.html (2014.8.25)

（18）独立行政法人労働政策研究・研修機構, 労働政策研究 報告書. 介護休業制度の利用拡大に向列て一「介護休 業制度の利用状況等に関する研究」報告書一No. 73 2006. http://www.jil.go.jp/institute/reports/2006/documents/ 073.pdf (2014.8.25)

（19）厚生労働省,「平成 23 年度雇用均等基本調査」の概況. http://www.mhlw.go.jp/toukei/list/d1/71-23r-05.pdf (2014. 8.25)

（20）日本医師会総合政策研究所，「院内保育所を含告医師 就労支援に関する調查（2008 年)」一No. 164 